\title{
Mineral Nitrogen Fertilizer and Compost Effects on Wheat and Maize Yields in Crop Sequences Including Intercropped Legumes
}

\author{
M.A. Abou-Keriasha and Nadia M.A. Eissa \\ Crop Intensification Research Department, Field Crops \\ Research Institute, Agricultural Research Center, Giza, Egypt.
}

\begin{abstract}
7 HE EXPERIMENT was conducted at Mallawi Agric. Res. Stn. 1 (Middle Egypt) during three years (2010/2011-2012/2013) to study mineral $\mathrm{N}$ fertilizer and compost effect on wheat and their residual effect on maize (second crop) in crop sequence. The experimental design was a split plot in a randomized complete blocks arrangement with three replications. The main plots were devoted to the three fertilizer treatments of wheat $(100 \%$ mineral $\mathrm{N}$ fertilizer, $50 \%$ compost $+50 \%$ mineral $\mathrm{N}$ fertilizer and $25 \%$ compost $+75 \%$ mineral $\mathrm{N}$ fertilizer)- 9 , while the sub plots were allocated to the three crop sequences, i.e. wheat/maize $\left(\mathrm{B}_{1}\right)$, wheat + faba bean/maize + cowpea/ fahl berseem $\left(\mathrm{B}_{2}\right)$ and wheat + fahl berseem/maize+soybean $\left(\mathrm{B}_{3}\right)$. The results showed that the grain yields of wheat and maize in the two fertilizer treatments that included compost were higher than the treatment receiving $100 \%$ mineral $\mathrm{N}$. The crop sequence (wheat + fahl berseem/maize + soybean $\left(B_{3}\right)$ ) produced the maximum value of weight of kernels/spike, weight of 1000 kernels and grain yield/fed of wheat. The crop sequence (wheat+ faba bean/maize + cowpea/clover $\left(\mathrm{B}_{2}\right)$ ) produced the maximum values of weight of 100 kernels and grain yield of maize. The yield and yield components of wheat or maize to which mineral $\mathrm{N}$ and compost were applied were lower in the first year than those obtained with $100 \%$ mineral N, while in the second and third years the values were higher. The yield and yield components of wheat or maize were higher in the third year than in second year and also those in the second year was higher than in the first year. The crop sequence $\left(\mathrm{B}_{2}\right)$ and the application of mineral $\mathrm{N}$ combined with compost at both rates $\left(\mathrm{A}_{2} \& \mathrm{~A}_{3}\right)$ had the highest values soil available N,P,K and organic matter $(\mathrm{OM})$ with values before planting. The results also show that growing wheat and maize in crop sequence with inclusion of legume intercrops $\left(B_{2}\right.$ and $\left.B_{3}\right)$ and fertilizing with mineral $\mathrm{N}$ fertilizer combined with compost $\left(\mathrm{A}_{2}\right.$ or $\left.\mathrm{A}_{3}\right)$ produced the highest values of intensification index and net return.
\end{abstract}

Keywords: Mineral $\mathrm{N}$ fertilizer, Compost, Triticum aestivum, Zea mays, Crop intensification

Wheat (Triticum aestivum L.) and maize (Zea mays L.) are important, welladapted grain crops in the world under irrigated and dry land conditions. Both crops are usually grown annually (not in rotation) or in a rotation involving both crops. In Egypt, most farmers have size holdings leading to planted the cereal 
crops (wheat and maize) in double crop sequences in the same area every year (monoculture rotation) which led to decreasing the yield.

Rotations avoid yield depressions under monoculture which increase populations of microorganisms that are pathogenic and decrease population of antagonistic microorganisms in the crop root rhizosphere (Cook, 1984) and reduce production of phytoxic allelopathic chemicals and improve physical and chemical conditions of soil (Barber, 1972). Arsheal et al. (1998) and Dogan \& Bilgili (2010) showed that grown cereal crops (wheat or maize) after legume crops produced more grain yield than those grown after non legume crops. Abou - Keriasha (1998) found that grain and straw yields of wheat grown in crop sequences maize/clover/wheat (3-crop sequence) were higher than in double crops (maize/wheat). Abd El-Hady et al. (2000) and Abou - Keriasha et al. (2012) showed that available NPK and organic matter were higher in second cycle than that of zero time and the first cycle of the crop rotation.

In cereal - legume rotation or intercropping systems, the cereal benefits from the nitrogen fixed by the legume and the decomposition of nutrient - vies biomass, root and nodules of legume which help to increase soil organic matter as well as reduces weeds population density and biomass production (Gregorich et al., 2001 and Chen et al., 2004). Thorstad et al. (2006), Abou - Keriasha et al. (2008) and Eskandari \& Ghanbari (2010) showed that plant height, spike length, no. of grains/spike, weight of 1000 grains and straw yield/fed of wheat were increased by intercropping with faba bean or white clover compared to wheat monoculture. El Naggar et al. (1991) and Yilmaz et al. (2007) showed that cereal crops grain yield was increased or not affected by intercropping systems compared with the sole crop, but legume crops yields were decreased. Fininsa (1997) found that the reduction in intercropped maize ranged from 10 to $15 \%$, while, this reduction in legume crops (bean or cowpea) ranged from 45 to $67 \%$ of pure stand.

Organic manures are well established to be involved in the fertilization of plants in most world countries, due to their direct and residual effect on the physical, chemical and biochemical characteristics of the soil, which in turn influence the growth and development of plants. Mahmoud (2000) showed that fertilizing the soils with compost increased the dry matter yield, grain and straw yield of sorghum. Delgado et al. (2002) showed that the greatest growth was obtained in mixed treatment $(12000 \mathrm{~kg} / \mathrm{ha}$ 'compost' $+380 \mathrm{~kg} / \mathrm{ha}$ 'urea') and $(8000 \mathrm{~kg} / \mathrm{ha}$ 'compost' $+350 \mathrm{~kg} / \mathrm{ha}$ 'urea') with 20 and $10 \%$ more mineral fertilizer, respectively.

Residual effects of manure or compost application can maintain crop yield level for several years after manure or compost application ceases since only a fraction of the $\mathrm{N}$ and the other nutrients in manure or compost become available to plant in the first year after application (Eghball et al., 2004). Drija \& Kazakove (1975) indicated that the grain yield of maize and winter wheat during three years was increased by $33 \%$ from the direct and residual effect of the Egypt. J. Agron . 36, No.2 (2014) 
application of 10 ton farm yard manure (FYM)/ha. Kapur (1995) reported that the residual effects were equivalent to $28 \mathrm{~kg} / \mathrm{ha}$ of urea $\mathrm{N} / \mathrm{ha}$ for sugar beet grown after corn and $22 \mathrm{~kg} / \mathrm{ha}$ for sugar beet after rice, respectively. Ramamurthy \& Shivashankor (1995) noted that the residual effect of application of 10 ton/ha organic manure significantly increased sunflower seed yield grown after soybean or maize plants compared with 0.0 or 5.0 ton/ha.

The purpose of this investigation was to study the effect of mineral $\mathrm{N}$ fertilizers, compost and legumes on wheat and maize yield in some crop sequences for the choice of proper system that will lead to increase production of wheat and maize grown in continuous crop sequences.

\section{Materials and Methods}

The experiment was conducted at Mallawi Agric. Res. Stn. \{Lat. 2743"55' N, Long. 30 $50^{\prime} 28^{\prime}$ E, $27 \mathrm{~m}$ a.s.1.\} (Middle Egypt) during three years (2010/2011, 2011/2012 and 2012/2013). The main objective of this study was to compare three crop sequences and three fertilizer treatments for wheat crop. The experimental design was split plot in a randomized complete blocks arrangement with three replications. The main plots were devoted to the three fertilizer treatments which were applied to the wheat once a year, i.e. $100 \%$ mineral $\mathrm{N}$ fertilizer $\left(\mathrm{A}_{1}\right), 50 \%$ compost $+50 \%$ mineral $\mathrm{N}\left(\mathrm{A}_{2}\right)$ and $25 \%$ compost $+75 \%$ mineral $\mathrm{N}\left(\mathrm{A}_{3}\right)$. The sub - plots were allocated for the three crop sequences which used, wheat/maize $\left(\mathrm{B}_{1}\right)$, wheat+faba bean/maize+cowpea/fahl berseem $\left(B_{2}\right)$ and wheat+fahl berseem/maize+soybean $\left(B_{3}\right)$. The sub-plot area was $6.0 \mathrm{~m}$ length $\times 0.7 \mathrm{~m}$ width $\left({ }_{100}\right.$ fed). Wheat seeds (c.v. Giza 168) at a seed rate of $60 \mathrm{~kg} / \mathrm{fed}$ were sown by hand drilling in rows $(20 \mathrm{~cm}$ between $)$ during the second and third week of November every year. Wheat + faba bean (intercrop): four wheat rows : two faba bean rows, $(80 \%$ wheat $+20 \%$ faba bean). Wheat + fahl berseem : $60 \mathrm{~kg}$ wheat seeds $+5 \mathrm{~kg}$ fahl berseem seeds $(100 \%$ wheat $+25 \%$ fahl berseem).

In the summer season of the three years (2011, 2012 and 2013), maize (cv. single cross 122) was grown in the same plots as the second crop (after harvested plants of wheat and intercropped crops). The maize grains (solid or intercropped) were planted during the second week of June on one side of the ridges $(70 \mathrm{~cm}$, width) with one plant per hill $(30 \times 70 \mathrm{~cm})$.

Maize+cowpea (intercrop): Cowpea was planted on the other side of all maize ridges with two plants per hill, $20 \mathrm{~cm}$ between (100\% maize+100\% cowpea). Maize+soybean (intercrop): two maize ridges : two soybean ridges (50\% maize $+50 \%$ soybean). Soybean was planted on the two sides of the ridge with one plant per hill $(20 \times 70 \mathrm{~cm})$. Maize and soybean plants were harvested during the second week of October, while, cowpea was cutting as fresh forage at the two month age. 
Addition of mineral nitrogen fertilizer for wheat at rate $70 \mathrm{~kg} \mathrm{~N} / \mathrm{fed}(100 \%$ recommended) in the form of ammonium nitrate (33.5\%) was in three doses (at sowing time, 21 and 45 days age). While, addition of compost was at two tons per fed (recommended for cereal crops) during soil preparation (one ton per fed for $50 \%$ compost and half ton for $25 \%$ compost). Organic compost was obtained from compost El-Nile Industry (Minia) which was manufactured from field crops, vegetables and fruit plants. Chemical analysis of compost is shown in Table 1. Nitrogen fertilizer maize (second crop) was at rate $112.5 \mathrm{~kg} \mathrm{~N} / \mathrm{fed}(75 \%$ of recommended) in three doses after thinning (21 days age) and before second and third irrigation. Calcium superphosphate $\left(15.5 \% \quad \mathrm{P}_{2} \mathrm{O}_{5}\right)$ was added at a rate of 30 and $45 \mathrm{~kg} \mathrm{P}_{2} \mathrm{O}_{5} / \mathrm{fed}$ for wheat and maize, respectively, during soil preparation. Potassium sulfate $\left(48 \% \mathrm{~K}_{2} \mathrm{O}\right)$ at a rate of 24 and $48 \mathrm{~kg} \mathrm{~K} \mathrm{~K}_{2} \mathrm{O} / \mathrm{fed}$ for wheat and maize, respectively.

In the winter season, of second and third years, wheat in first and second crop sequences was planted in the same plots in the second week of November (after harvest of maize plants). While, wheat in second crop sequence was planted after cutting fahl berseem (first week of December) which was planted in the last week of October. Soil samples before sowing wheat \& wheat intercrops (first year) and harvesting maize $\&$ maize intercrops in the last year (third year) at 0 $30 \mathrm{~cm}$ were collected from all treatments and analyzed for organic matter (OM) and available N, P, K according to Black (1965). The other normal cultural practices (irrigation, weed, pests and diseases) were practiced as recommended for each crop (wheat $\&$ maize).

At harvesting: The following data on plants were recorded as:

Wheat and intercropped

The plants of each sub plot were harvested and recorded the yield components characters of wheat (spike length, number of spikes $/ \mathrm{m}^{2}$, number of kernels/spike, weight of kernels/spike and weight of 100 kernels). Grain and seed yield of wheat, faba bean and fahl berseem were determined from sub plot area $(\mathrm{kg} / \mathrm{sub}$ plot) and calculated as ardab per fed. (ardab of wheat $=150 \mathrm{~kg}$ and ardab of faba bean $=155 \mathrm{~kg}$ ).

\title{
Maize and intercropped
}

The plants of each sub plot were harvested and recorded yield components of maize (number of ears/plant, weight of kernels/ear and weight of 100 kernels). Grain yield of maize, seed yield of soybean and forage yield of cowpea were determined from each sub plot (kg/sub plot) and calculated as ardab per fed (ardab for maize, ton for soybean seeds and forage cowpea). (Ardab of maize $=140 \mathrm{~kg}$ ).

\author{
Farmer's benefit \\ Intensification index \\ The intensification index was calculated using the following formula: \\ Intensification index $=($ crop area/land area $)$ \\ or $=$ (number of crops grown in one year/the cultivated
}

area) according to Shafshak \& Debaby (1975).

Egypt. J. Agron . 36, No.2 (2014) 
MINERAL NITROGEN FERTILIZER AND COMPOST ...

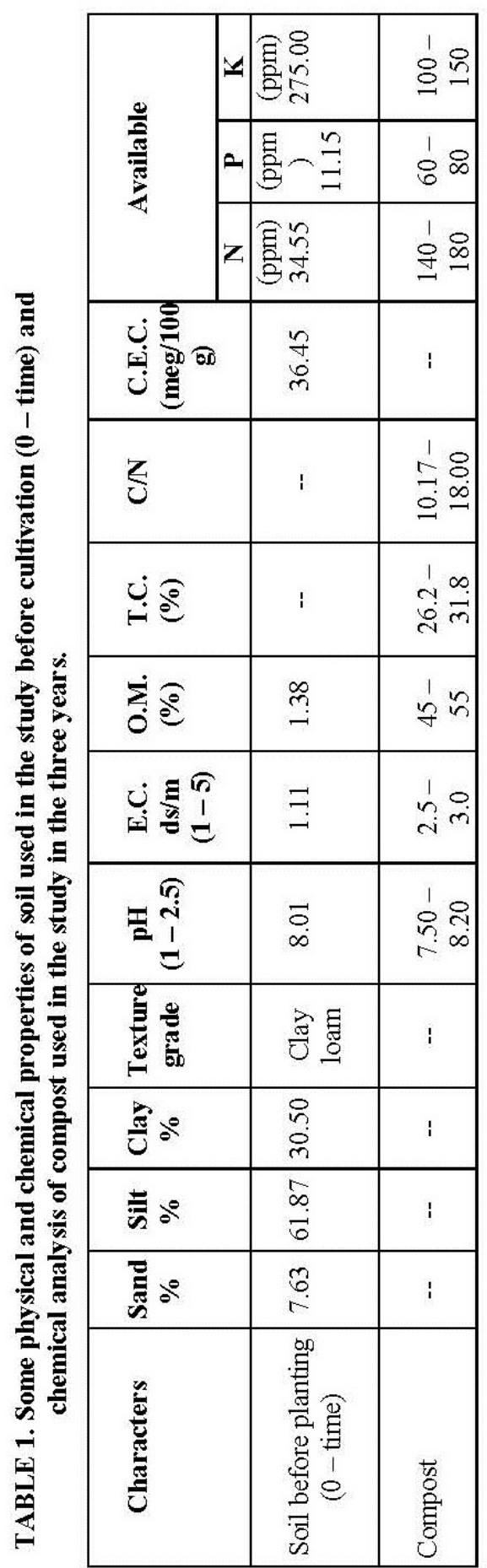

Egypt. J. Agron . 36, No. 2(2014) 
Economic evaluation

To calculate the net return of the three crops sequences, the following market prices with Egyptian pound (L.E.) were used: 2800 L.E./ton for wheat, 2500 L.E./ ton for maize, 3200 L.E./ton for faba bean, 1200 L.E./ton for soybean, 20 L.E./ kg seed for fahl berseem, 250 L.E./ton for green forage of both clover and cowpea, 250 L.E./ton compost and 2000 L.E./ton of urea fertilizer (Agricultural Statistics, 2010).

Statistical analysis

$$
\text { Total revenue }=\text { total cost }+ \text { net return }
$$

The statistical analysis was carried out for both crops (wheat and maize) in each year and across the three years according to Snedecor \& Cochran (1980), through MSTAT-C (1980) software and treatment means were compared by least significant differences (LSD) test at $5 \%$ level of probability.

\section{Results and Discussion}

Wheat

Effect of applying either mineral $N$ fertilizer alone or combined with compost

Data presented in Table 2 showed that there were significant differences for most studied characters of wheat in the first, second and third years and for the combined analysis. The application of $50 \%$ compost $+50 \%$ mineral $\mathrm{N}\left(\mathrm{A}_{2}\right)$ produced the maximum values in the second and third years and combined years, while, the application of $100 \%$ mineral $\mathrm{N}$ fertilizer $\left(\mathrm{A}_{1}\right)$ produced the minimum values in the second and third years. Analysis of the combined years revealed that the values of most studied characters of wheat in the two fertilizer treatments that included compost $(50 \%$ compost $+50 \%$ mineral $\mathrm{N}$ and $25 \%$ compost $+75 \%$ mineral $\mathrm{N}$ ) were higher compared to $100 \%$ mineral $\mathrm{N}$ fertilizer $\left(A_{1}\right)$. The percentage increases in the treatments $A_{2}$ and $A_{3}$ compared to $A_{1}$, were 6.2 and $4.7 \%$ for number of kernels/spike, 10.06 and $6.2 \%$ for weight of kernels/spike, 4.3 and $5.8 \%$ for weight of 1000 kernels and 3.8 and $13.6 \%$ for straw yield/fed, respectively.

In general, the mean values obtained from mineral fertilizer combined with compost $\left(\mathrm{A}_{2}+\mathrm{A}_{3}\right)$ during the first year were lower than those obtained from $100 \%$ mineral fertilizer, while in the second and third years, the means were higher than those obtained from the application of $100 \%$ mineral $\left(\mathrm{A}_{1}\right)$. The increases in the second and third years (averages of $\mathrm{A}_{2}$ and $\mathrm{A}_{3}$ ) were 7.4 and $20.3 \%$ for number of spikes $/ \mathrm{m}^{2}, 4.2$ and $7.7 \%$ for number of kernels/spike, 7.4 and $11.1 \%$ for weight of 1000 kernels and 16.4 and $20.8 \%$ for grain yield over the first year, respectively. These results clear that the increasing of yield and yield components in the third year was higher than the second year. These increases in second and third years could be attributed to the residual effect of the application of annual compost which resulted in improvement of physical and chemical properties of soil and nutrient contents of the soil and consequently increased wheat production. Such results are in agreement with those of Eghball et al. (2004).

Egypt. J. Agron . 36, No.2 (2014) 


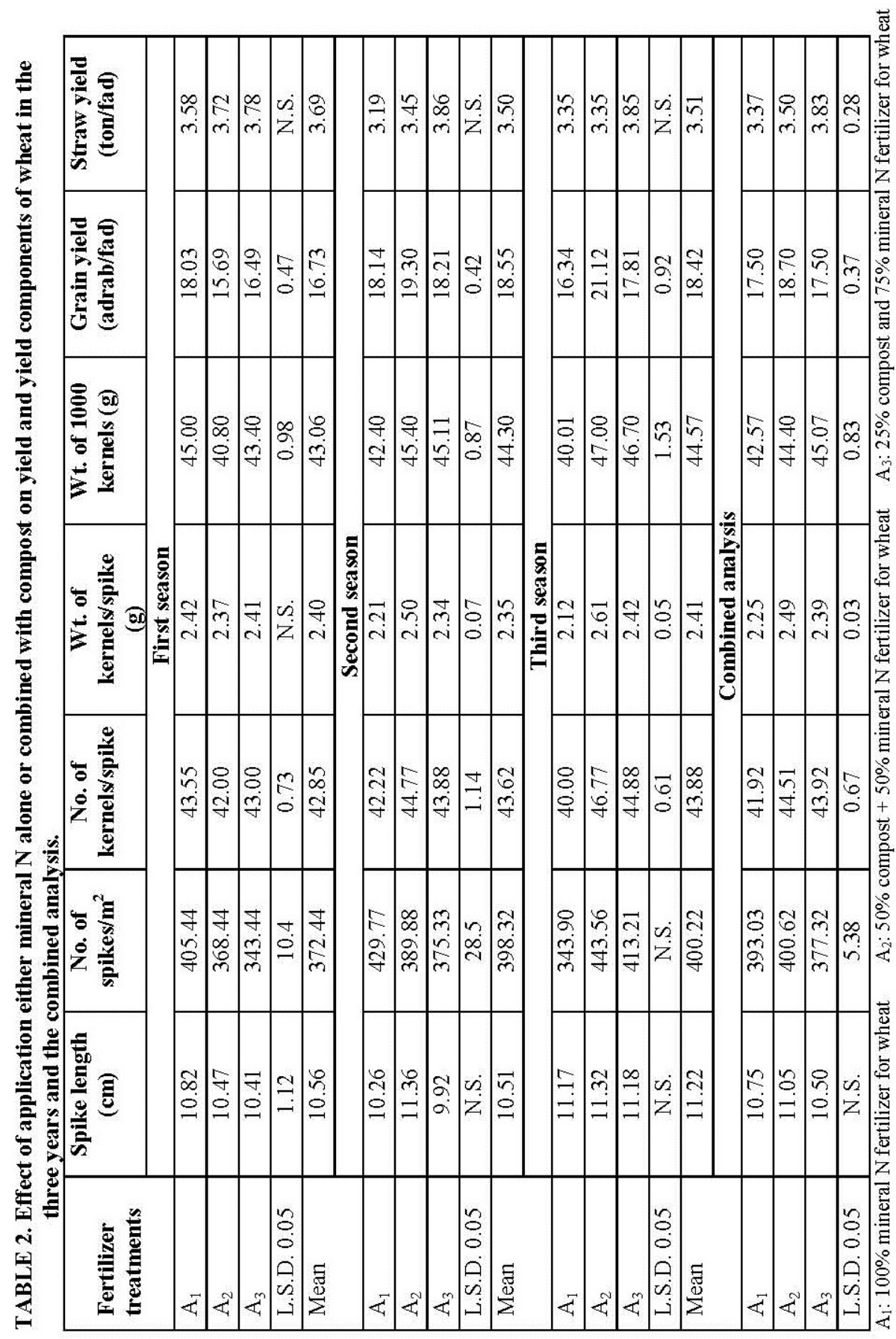




\section{Effect of crop sequences}

Data in Table 3 showed significant differences in most studied characters in the first, second, third years and the combined analysis. The crop sequence, wheat/maize $\left(B_{1}\right)$ produced the maximum values of number of spikes $/ \mathrm{m}^{2}$, grain yield and straw yield in the first year only. The values of yield and yield components in the second and third crop sequences, wheat + faba bean/maize+ cowpea/fahl berseem $\left(B_{2}\right)$ and wheat + fahl berseem/maize+ cowpea $\left(B_{3}\right)$ were higher than the crop sequence, wheat/maize $\left(B_{1}\right)$ in the second and third years. The increase in yield and its components in the two crop sequences $\left(\mathrm{B}_{2}\right.$ and $\left.\mathrm{B}_{3}\right)$ was due to residual effects of crop sequences and inclusion of legume crops which improved soil fertilizer in the second and third year compared with the crop sequence, wheat/maize ' $\mathrm{B}_{1}$ ' (Barber, 1972 and Cook, 1984).

Data in the combined analysis showed that the crop sequence, wheat + fahl berseem/maize + soybean $\left(B_{3}\right)$ produced the maximum values of weight of kernels/spike, weight of 1000 kernels and grain yield/fed. While, the crop sequence, wheat + faba bean/ maize + cowpea/fahl berseem $\left(B_{2}\right)$ produced the maximum values of spike length and number of kernels/spike and the minimum values of number of spikes $/ \mathrm{m}^{2}$ and grain yield/fed. The crop sequence, wheat/maize $\left(B_{1}\right)$ produced the minimum values of all studied characters except number of spikes $/ \mathrm{m}^{2}$ and straw yield. The increase in the third crop sequence was estimated to be $3.0 \%$ and $1.7 \%$ for weight of kernels/spike, 0.3 and $0.06 \%$ for weight of 1000 kernels and 2.5 and $34.7 \%$ for grain yield/fed over $B_{1}$ and $B_{2}$, respectively. The reduction of grain yield in the second crop sequence (wheat + faba been/maize + cowpea/fahl berseem) due to the plant density of wheat was $80 \%$ of solid which led to reduced number of spike $/ \mathrm{m}^{2}$ and wheat productivity. Similar results were obtained by Eskandari \& Ghanbari (2010) and Abou-Keriasha et al. (2012).

\section{Interaction effects}

There was no significant interaction between nitrogen fertilizer (mineral $\mathrm{N}$ alone or combined with compost) and crop sequence for all studied characters, except for number of spike $/ \mathrm{m}^{2}$ and grain and straw yield/fed, where the effect of nitrogen fertilizer and crop sequences were generally additive (Table 4). The results show that the third crop sequence (wheat + fahl berseem/maize + cow pea) and application of $50 \%$ compost $+50 \%$ mineral $\mathrm{N}\left(\mathrm{A}_{2} \mathrm{~B}_{3}\right)$ produced the maximum values of grain yield/fed, while, the first crop sequence $\left(\mathrm{B}_{1}\right)$ and application $50 \%$ compost $+50 \%$ mineral $\mathrm{N}$ $\left(A_{2} B_{1}\right)$ produced the maximum values of number of spike $/ \mathrm{m}^{2}$. 


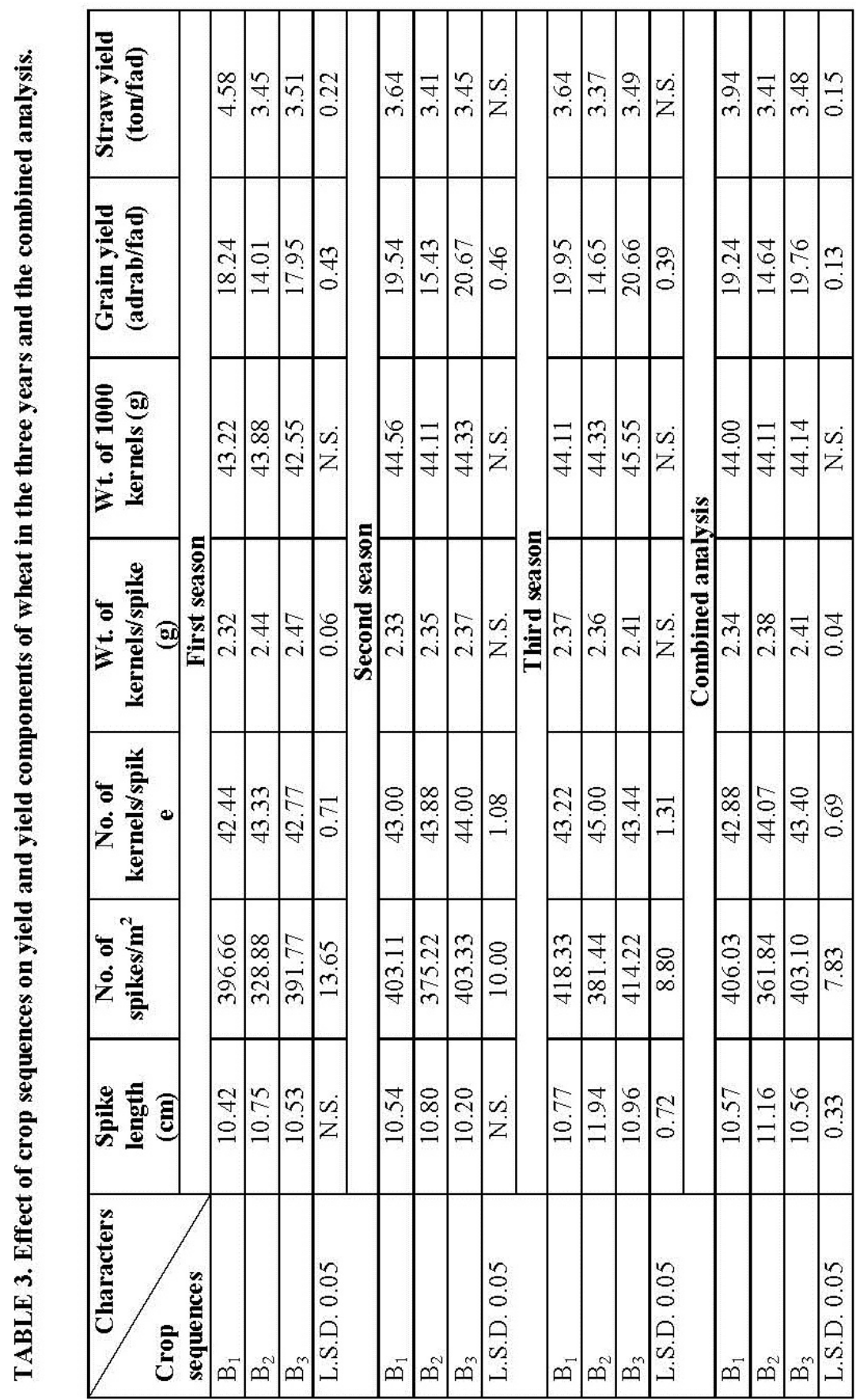




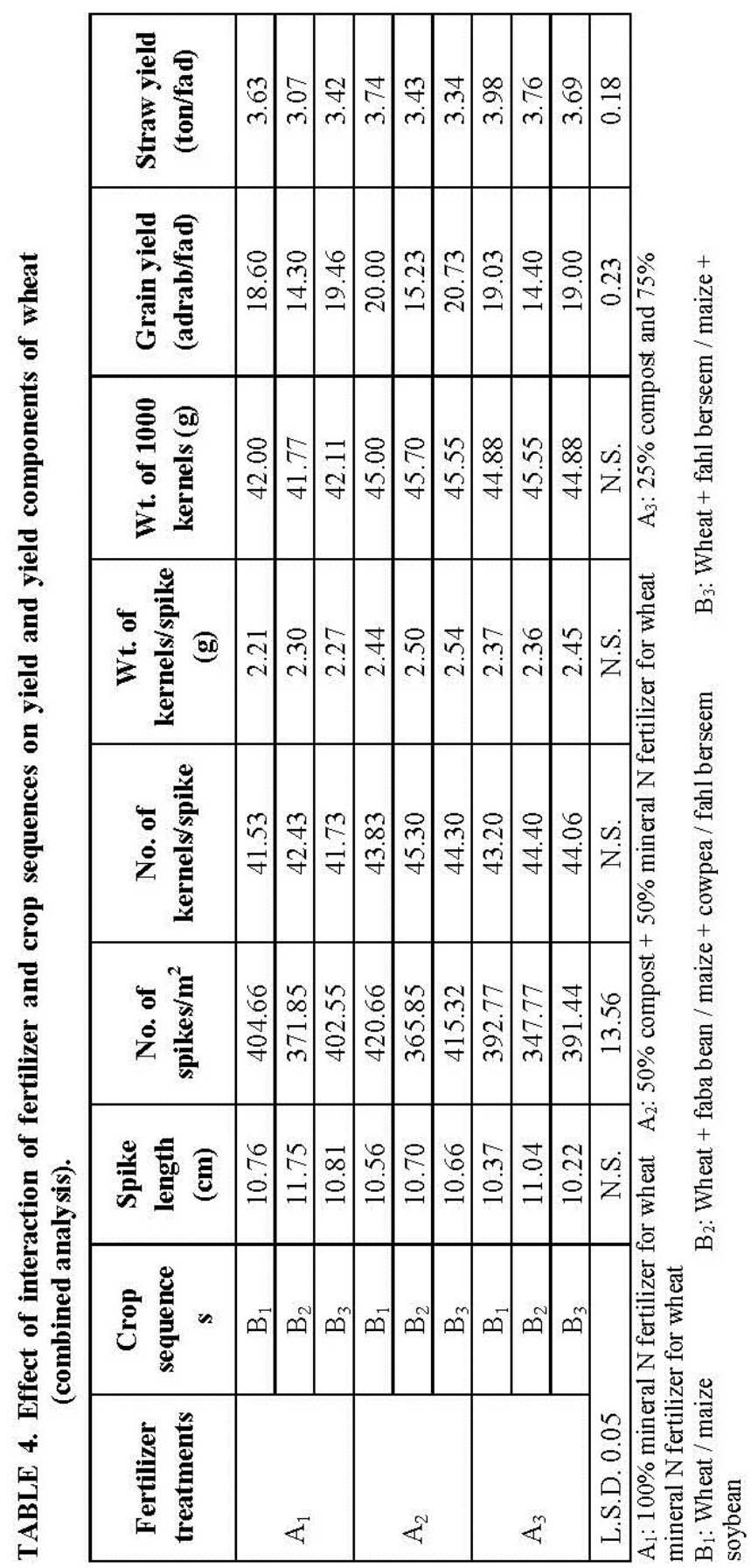

Egypt. J. Agron . 36, No.2 (2014) 
Maize

Residual effect of mineral $N$ fertilizer alone or combined with compost

Data in Table 5 showed that maize grown after wheat which was fertilized with $100 \%$ mineral $\mathrm{N}\left(\mathrm{A}_{1}\right)$ produced the maximum values of weight of kernels/ear and weight of 100 kernels in the first and their combined data. While maize grown after wheat which was fertilizerd with $50 \%$ compost $+50 \%$ mineral $\mathrm{N}$ produced the maximum values of most studied characters (number of ears/plant, weight of 100 kernels and grain yield/fed) in the second and third years. The increase in maize grown after wheat which was fertilized with $50 \%$ compost $+50 \%$ mineral $\mathrm{N}\left(\mathrm{A}_{2}\right)$ in the three years and the combined analysis was estimated by $17.4,7.2,7.6$ and $12.3 \%$ for number of ears/plant and 3.7, 20.2, 61.0 and 27.4\% for grain yield over application of $100 \%$ mineral $\mathrm{N}$ fertilizer (control), respectively. Maize grown after wheat which was fertilized with $25 \%$ compost $+75 \%$ mineral $\mathrm{N}$ produced the minimum values in the three years in most characters. The reduction in grain yield of maize grown after wheat which was fertilized with $25 \%$ compost $+75 \%$ mineral $\mathrm{N}$ $\left(\mathrm{A}_{3}\right)$ may be due to the rate of $\mathrm{N}$ fertilizer added with $75 \%$ recommended which was not enough.

TABLE 5. Residual effect of fertilizing wheat with mineral alone or combined with compost on yield and yield components of maize in the three years and the combined analysis.

\begin{tabular}{|c|c|c|c|c|}
\hline \multirow{2}{*}{$\begin{array}{l}\text { Characters } \\
\text { Fertilizer } \\
\text { treatments }\end{array}$} & $\begin{array}{c}\begin{array}{c}\text { No. of } \\
\text { ears/plant }\end{array} \\
\end{array}$ & $\begin{array}{c}\text { Wt. of } \\
\text { kernels/ear (g) }\end{array}$ & $\begin{array}{l}\text { Wt. of } 100 \\
\text { kernels (g) }\end{array}$ & $\begin{array}{l}\text { Grain yield } \\
\text { (adrab/fad) }\end{array}$ \\
\hline & \multicolumn{4}{|c|}{ First season } \\
\hline$A_{1}$ & 1.00 & 219.22 & 37.95 & 20.11 \\
\hline $\mathrm{A}_{2}$ & 1.21 & 205.44 & 33.51 & 20.86 \\
\hline $\mathrm{A}_{3}$ & 1.00 & 206.55 & 33.88 & 17.42 \\
\hline L.S.D. 0.05 & 0.04 & 4.31 & 2.4 & 1.1 \\
\hline \multirow[t]{2}{*}{ Mean } & 1.08 & 210.40 & 35.11 & 19.46 \\
\hline & \multicolumn{4}{|c|}{$\begin{array}{l}\text { Second season } \\
\end{array}$} \\
\hline $\mathrm{A}_{1}$ & 1.10 & 205.00 & 31.44 & 18.60 \\
\hline $\mathrm{A}_{2}$ & 1.18 & 217.88 & 32.00 & 22.37 \\
\hline $\mathrm{A}_{3}$ & 1.11 & 188.88 & 30.66 & 17.63 \\
\hline L.S.D. 0.05 & 0.04 & 8.40 & N.S. & N.S. \\
\hline \multirow[t]{2}{*}{ Mean } & 1.13 & 203.92 & 31.36 & 19.53 \\
\hline & \multicolumn{4}{|c|}{ Third season } \\
\hline $\mathrm{A}_{1}$ & 1.05 & 221.44 & 30.98 & 18.00 \\
\hline $\mathrm{A}_{2}$ & 1.13 & 205.44 & 32.94 & 29.05 \\
\hline $\mathrm{A}_{3}$ & 1.08 & 190.77 & 30.20 & 18.72 \\
\hline L.S.D. 0.05 & N.S. & 12.3 & N.S. & 1.5 \\
\hline \multirow[t]{2}{*}{ Mean } & 1.08 & 205.84 & 31.37 & 21.94 \\
\hline & \multicolumn{4}{|c|}{ Combined analysis } \\
\hline $\mathrm{A}_{1}$ & 1.05 & 215.22 & 33.46 & 18.91 \\
\hline $\mathrm{A}_{2}$ & 1.18 & 209.58 & 32.81 & 24.10 \\
\hline $\mathrm{A}_{3}$ & 1.06 & 195.41 & 31.43 & 17.92 \\
\hline L.S.D. 0.05 & 0.03 & 5.5 & 1.16 & 0.76 \\
\hline
\end{tabular}

$\mathrm{A}_{1}: 100 \%$ mineral $\mathrm{N}$ fertilizer for wheat $\quad \mathrm{A}_{2}: 50 \%$ compost $+50 \%$ mineral $\mathrm{N}$ fertilizer for wheat $A_{3}: 25 \%$ compost and $75 \%$ mineral $\mathrm{N}$ fertilizer for wheat 
Generally, the mean values of the yield and yield components of maize under application of both $A_{1} \& A_{2}$ in the second and third years were higher than those under application of $100 \%$ mineral fertilizer $\left(A_{1}\right)$. This indicated the beneficial residual effect of compost used. Our results are in agreement with those reported by Kapur (1995), Ramamurthy \& Shirashankar (1995) and Eghball et al. (2004).

Effect of crop sequences

Data in Table 6 showed insignificant effect of crop sequences on all studied characters of maize, except weight of kernels/ear in third year and grain yield in the first year and the combined analysis. Maize grown in the crop sequence $\left(\mathrm{B}_{2}\right)$ produced the maximum values of grain yield in first year and the combined analysis. Maize grown in the third crop sequence, wheat + fahl berseem/maize + soybean $\left(\mathrm{B}_{3}\right)$ produced the maximum values of weight of kernels/ear and the minimum values of grain yield in first year and the combined analysis. This reduction in grain yield of maize in the third crop sequence was due to the fact that plant density in maize + soybean was equal to $50 \%$ of solid. Similar results were observed by Fininsa (1997) and Abou-Keriasha et al. (2012).

\section{Interaction effect}

There was no significant interaction between fertilizer treatment and crop sequences for any studied characters.

TABLE 6. Effect of crop sequences on yield and yield components of maize in the three years and the combined analysis.

\begin{tabular}{|c|c|c|c|c|}
\hline \multirow{2}{*}{$\begin{array}{l}\text { Characters } \\
\text { Crop } \\
\text { sequences }\end{array}$} & $\begin{array}{c}\text { No. of } \\
\text { ears/plant }\end{array}$ & $\begin{array}{c}\text { Wt. of } \\
\text { kernels/ear(g) }\end{array}$ & $\begin{array}{l}\text { Wt. of } 100 \\
\text { kernels (g) }\end{array}$ & $\begin{array}{l}\text { Grain yield } \\
\text { (adrab/fad) }\end{array}$ \\
\hline & \multicolumn{4}{|c|}{ First season } \\
\hline $\mathrm{B}_{1}$ & 1.05 & 207.44 & 35.02 & 19.11 \\
\hline $\mathrm{B}_{2}$ & 1.06 & 209.66 & 35.11 & 20.66 \\
\hline $\mathrm{B}_{3}$ & 1.10 & 214.11 & 35.22 & 18.62 \\
\hline \multirow[t]{2}{*}{ L.S.D. 0.05} & N.S. & N.S. & N.S. & 0.8 \\
\hline & \multicolumn{4}{|c|}{ Second season } \\
\hline $\mathrm{B}_{1}$ & 1.10 & 201.33 & 30.44 & 20.04 \\
\hline $\mathrm{B}_{2}$ & 1.14 & 201.44 & 32.00 & 19.42 \\
\hline $\mathrm{B}_{3}$ & 1.14 & 209.00 & 31.66 & 19.14 \\
\hline \multirow[t]{2}{*}{ L.S.D. 0.05} & N.S. & N.S. & N.S. & N.S. \\
\hline & \multicolumn{4}{|c|}{$\begin{array}{c}\text { Third season } \\
\end{array}$} \\
\hline $\mathrm{B}_{1}$ & 1.05 & 204.66 & 30.83 & 20.31 \\
\hline $\mathrm{B}_{2}$ & 1.10 & 199.44 & 31.81 & 22.27 \\
\hline $\mathrm{B}_{3}$ & 1.10 & 213.55 & 31.48 & 19.27 \\
\hline \multirow[t]{2}{*}{ L.S.D. 0.05} & N.S. & 10.06 & N.S. & N.S. \\
\hline & \multicolumn{4}{|c|}{ Combined analysis } \\
\hline $\mathrm{B}_{1}$ & 1.06 & 204.47 & 32.09 & 19.82 \\
\hline $\mathrm{B}_{2}$ & 1.10 & 203.51 & 32.97 & 20.78 \\
\hline $\mathrm{B}_{3}$ & 1.11 & 212.22 & 32.18 & 19.01 \\
\hline L.S.D. 0.05 & N.S. & N.S. & N.S. & 0.71 \\
\hline
\end{tabular}

$\mathrm{B}_{1}$ : Wheat / maize $\quad \mathrm{B}_{2}$ : Wheat + faba bean / maize + cowpea / fahl berseem

$\mathrm{B}_{3}$ : Wheat + fahl berseem / maize + soybean

Egypt. J. Agron . 36, No.2 (2014) 
Effect of fertilizer (mineral $N$ and compost) and crop sequence on soil available $N, P$ and $K$ and organic matter

Data presented in Table 7 showed that the available N, P and K contents and organic matter in soil were increased due to the applications of $50 \%$ compost $+50 \%$ mineral $\mathrm{N}\left(\mathrm{A}_{2}\right)$ followed by the application of $25 \%$ compost $+75 \%$ mineral $\mathrm{N}\left(\mathrm{A}_{3}\right)$, while the application of $100 \%$ mineral $\mathrm{N}\left(\mathrm{A}_{1}\right)$ decreased these available nutrients and $\mathrm{OM}$ after three years compared with soil analysis before the experiment began $(0-$ time). The increases from the application of $50 \%$ compost $+50 \%$ mineral $\mathrm{N}$ were $35.02 \%$ for N, $42.14 \%$ for $\mathrm{P}, 29.83 \%$ for $\mathrm{K}$ and $15.32 \%$ for OM compared to mineral $\mathrm{N}$ alone. While, the increase resulted from the application of $25 \%$ compost $+75 \%$ mineral $\mathrm{N}$ was $29.2 \%$ for $\mathrm{N}, 33.19 \%$ for $\mathrm{P}, 26.55 \%$ for $\mathrm{K}$ and $12.92 \%$ for OM. It is clear that NPK and OM were increased with increasing rate of the compost. Increasing NPK contents and organic matter in the soil due to the application of compost might be a result of its decomposition and the production of organic acids, which increase the nutrients availability and organic matter in soil. Similar results were reported by Kapur (1995) and Ramamurthy \& Shivashankav (1995).

TABLE 7. Effect of application of mineral $N$ alone or combined with compost and crop sequences on NPK contents and organic matter (OM) levels in soil last year (third year).

\begin{tabular}{|c|c|c|c|c|c|}
\hline \multirow{2}{*}{\multicolumn{2}{|c|}{ Crop sequences }} & \multicolumn{3}{|c|}{ Available nutrients (ppm) } & \multirow{2}{*}{$\underset{(\%)}{\text { O.M. }}$} \\
\hline & & $\mathbf{N}$ & $\mathbf{P}$ & $\mathbf{K}$ & \\
\hline \multicolumn{2}{|c|}{ Before planting $(0-$ time $)$} & 34.55 & 11.15 & 275.0 & 1.38 \\
\hline \multirow{4}{*}{$\mathrm{A}_{1}$} & $\mathrm{~B}_{1}$ & 24.65 & 9.05 & 268.0 & 1.23 \\
\hline & $\mathrm{B}_{2}$ & 30.50 & 9.80 & 267.0 & 1.25 \\
\hline & $\mathrm{B}_{3}$ & 30.00 & 10.00 & 279.0 & 1.25 \\
\hline & Mean & 28.35 & 9.61 & 276.6 & 1.24 \\
\hline \multirow{4}{*}{$\mathrm{A}_{2}$} & $\mathrm{~B}_{1}$ & 33.60 & 11.50 & 315.0 & 1.30 \\
\hline & $\mathrm{B}_{2}$ & 41.75 & 15.80 & 375.0 & 1.55 \\
\hline & $\mathrm{B}_{3}$ & 39.50 & 13.70 & 372.0 & 1.49 \\
\hline & Mean & 38.28 & 13.66 & 354.0 & 1.43 \\
\hline \multirow{4}{*}{$\mathrm{A}_{3}$} & $\mathrm{~B}_{1}$ & 34.15 & 10.10 & 305.0 & 1.29 \\
\hline & $\mathrm{B}_{2}$ & 38.90 & 14.50 & 361.0 & 1.46 \\
\hline & $\mathrm{B}_{3}$ & 36.80 & 13.80 & 359.0 & 1.45 \\
\hline & Mean & 36.63 & 12.80 & 345.0 & 1.48 \\
\hline & $\mathrm{B}_{1}$ & 30.80 & 10.20 & 296.0 & 1.27 \\
\hline & $\mathrm{B}_{2}$ & 37.05 & 13.36 & 334.3 & 1.42 \\
\hline & $\mathrm{B}_{3}$ & 35.43 & 12.50 & 336.1 & 1.39 \\
\hline
\end{tabular}

The data also show that soil content of NPK and organic matter were increased in the two crop sequences which include legume crops. The maximum values of soil content of available NPK and organic matter were recorded with the second crop sequence, wheat + faba bean / maize + cowpea / fahl berseem $\left(\mathrm{B}_{2}\right)$. While, the minimum values were recorded with the first crop sequence (control). This increase in $\mathrm{N}, \mathrm{P}, \mathrm{K}$ contents and $\mathrm{OM}$ levels in the two crop sequences which include legume crops may be due to the residual effect of interaction between the legume crops (faba bean, cowpea and fahl berseem) and 
compost that improve soil fertility and macro and micro environmental factors. These observation are in agreement with Thorsted et al. (2006).

\section{Farmer's benefit}

Effect of fertilizer (mineral and compost) and crop sequence effect on intensification index

Data in Table 8 show that fertilizer treatments had a small effect on intensification index. However, the intensification index for treatments including compost $\left(A_{2}\right.$ and $\left.A_{3}\right)$ were higher than for the application of $100 \%$ mineral $N$. The intensification in the second and third crop sequences $\left(\mathrm{B}_{2}\right.$ and $\left.\mathrm{B}_{3}\right)$ was increased by 37.0 and $30.0 \%$, respectively, compared to the control. The maximum value of intensification index (2.81) was recorded by the second crop sequence (3-crop sequence) with application of $50 \%$ compost $+50 \%$ mineral $\mathrm{N}$ or $100 \%$ mineral $\mathrm{N}$.

TABLE 8. Effect of application (mineral $N$ alone or combined with compost) and crop sequences on intensification index and average of net return $x 1000$.

\begin{tabular}{|c|c|c|c|c|c|}
\hline \multirow[b]{2}{*}{$\begin{array}{l}\text { Fertilizer } \\
\text { treatments }\end{array}$} & \multirow[b]{2}{*}{$\begin{array}{c}\text { Crop } \\
\text { sequences }\end{array}$} & \multirow[b]{2}{*}{$\begin{array}{l}\text { Intensification } \\
\text { index }\end{array}$} & \multicolumn{3}{|c|}{ Economic evaluation (L.E.) } \\
\hline & & & $\begin{array}{c}\text { Total } \\
\text { revenue }\end{array}$ & $\begin{array}{l}\text { Total } \\
\text { cost }\end{array}$ & $\begin{array}{c}\text { Net } \\
\text { return }\end{array}$ \\
\hline \multirow{4}{*}{$\mathrm{A}_{1}$} & $\mathrm{~B}_{1}$ & 2.00 & 14.609 & 7.407 & 7.200 \\
\hline & $\mathrm{B}_{2}$ & 2.81 & 18.944 & 7.617 & 11.330 \\
\hline & $\mathrm{B}_{3}$ & 2.54 & 16.480 & 7.562 & 8.930 \\
\hline & Mean & 2.45 & 16.680 & 7.530 & 9.150 \\
\hline \multirow{4}{*}{$\mathrm{A}_{2}$} & $\mathrm{~B}_{1}$ & 2.00 & 16.780 & 7.407 & 9.370 \\
\hline & $\mathrm{B}_{2}$ & 2.81 & 21.172 & 7.617 & 13.689 \\
\hline & $\mathrm{B}_{3}$ & 2.63 & 18.689 & 7.562 & 11.280 \\
\hline & Mean & 2.48 & 18.880 & 7.530 & 11.440 \\
\hline \multirow{4}{*}{$\mathrm{A}_{3}$} & $\mathrm{~B}_{1}$ & 2.00 & 14.180 & 7.407 & 6.770 \\
\hline & $\mathrm{B}_{2}$ & 2.60 & 18.656 & 7.617 & 11.04 \\
\hline & $\mathrm{B}_{3}$ & 2.63 & 16.393 & 7.562 & 8.830 \\
\hline & Mean & 2.47 & 16.410 & 7.562 & 8.880 \\
\hline & $\mathrm{B}_{1}$ & 2.00 & 15.190 & 7.407 & 7.780 \\
\hline & $\mathrm{B}_{2}$ & 2.74 & 19.590 & 7.617 & 12.020 \\
\hline & $\mathrm{B}_{3}$ & 2.60 & 17.187 & 7.617 & 9.680 \\
\hline
\end{tabular}

$\mathrm{A}_{1}: 100 \%$ mineral $\mathrm{N}$ fertilizer for wheat

$\mathrm{A}_{2}: 50 \%$ compost $+50 \%$ mineral $\mathrm{N}$ fertilizer for wheat

$\mathrm{A}_{3}: 25 \%$ compost and $75 \%$ mineral $\mathrm{N}$ fertilizer for wheat

$\mathrm{B}_{1}$ : Wheat / maize

$\mathrm{B}_{2}$ : Wheat + faba bean / maize + cowpea / fahl berseem

$\mathrm{B}_{3}$ : Wheat + fahl berseem / maize + soybean

Effect of fertilizer (mineral $N$ and compost) and crop sequence on the average of net return (combined analysis of the three years).

Data in Table 8 revealed that the application of $50 \%$ compost $+50 \%$ mineral $\mathrm{N}$ recorded the maximum values of total revenue and net return, while the application of $25 \%$ compost $+75 \%$ mineral $\mathrm{N}$ recorded the minimum values. The increase in the application of $50 \%$ compost $+50 \%$ mineral $\mathrm{N}$ was 13.19 and $25.03 \%$ for total revenue and net return over the application of $100 \%$ mineral $\mathrm{N}$.

Egypt. J. Agron . 36, No.2 (2014) 
While for the application of $25 \%$ compost $+75 \%$ mineral $\mathrm{N}$, total revenue and net return were reduced by 1.6 and $2.9 \%$ as compared the application of $100 \%$ mineral, respectively.

Data also show that the values of total revenue and net return were increased in the second and third crop sequences $\left(B_{2}\right.$ and $\left.B_{3}\right)$ as compared to the first crop sequence $\left(B_{1}\right)$. These increases in the second crop sequences were 28.96 and $54.49 \%$, while, the increase in the third crop sequence were 13.15 and $24.42 \%$ over the first crop sequence $\left(\mathrm{B}_{1}\right)$, respectively. Similar results were reported by Abou - Keriasha et al. (2012).

Finally, the results indicated that the crop sequences which include legume crops and use mineral $\mathrm{N}$ fertilizer combined with compost led to increase in soil $\mathrm{N}, \mathrm{P}, \mathrm{K}$ and $\mathrm{OM}$ contents thereby enhancing soil fertility and increased the production of wheat and maize grown in continuous crop sequences.

\section{References}

Abd El-Hadi, A.H., Abo El-Enein, R.A. and Omran, A. (2000) Sustainability of soil fertility status after 2 - cycles of three crop rotation at Middle Egypt region. $X^{\text {th }}$ Inter. Colloquium for the Optimization of Plant Nutrition. April $8-13,2000$, Cairo Sheraton, Cairo, Egypt. National Research Center.

Abou-Keriasha, M.A. (1998) Effect of preceding crops and $\mathrm{N}$ fertilizer on the productivity of wheat. J. Agric. Sci., Mansoura Univ. 23 (3), $961-967$.

Abou-Keriasha, M.A., Gadallah, R.A. and Badr, M.M.A. (2008) Effect of preceding and intercropping crops on yield and yield components of wheat. Minufiya J. Agric. Res. 33 (3),709-728.

Abou-Keriasha, M.A., Mohamed, Wafaa Kh., Eisa, Nadia M. and Kamel, A.S. (2012) Intensive crop rotations to improve agricultural production in Middle Egypt. Egypt. J. Agric Res. 90 (4), $427-443$.

Agricultural Statistics (2010) "Study of Indicator of the Agricultural Statistics". Ministry of Agriculture and Land Reclamation, Economics, Affairs Sector, Vol. 2 - Egypt.

Arsheal, M.A.,Gili, K.S. and Izourralde, R. (1998) Wheat production, weed population and soil properties subsequent to 20 years of sod as affected by crop rotation and tillage. J. Sustain. Agric. 12 (213), $131-154$.

Barber, S.A. (1972) Relations of chalmers silt loam. Agron. J. 64, 8 - 10.

Black, C.A. (1965) "Methods of Soil Analysis". Part 1 and 11. Amer. Soc. Agro. Inc. Publ. Madison Wisc, USA.

Chen, C., Westcott, M., Neill, K., Wichman, D. and Knox, M. (2004) Row configuration and nitrogen application for barley - pea intercropping organic farming. International J. of Pest Management, 56 (2),173 - 181.

Cook, R.J. (1984) Root Health Importance and Relationship to Farming Practices. In: "Organic Farming Current Technology and Its Role in a Sustainable Agriculture",

Egypt. J. Agron. 36, No. 2(2014) 
D.F. Bezdicek and J.F. Power (Ed.) pp. 111 - 127, ASA Spec. Publ., 46, ASA, CSSA, SSSA, Madison, WS.

Delgado, M.M., Porcel, M.A., Miralles, R., Beltran, E., Beringol, A. and Martin, J. (2002) Sewage Sludge compost fertilizer effect on maize yield and soil heavy metal concentration. Rev. Int. Contam. Ambient, 18 (3), 147 - 150.

Dogan, R. and Bilgili, U. (2010) Effects of previous crop and N - fertilization on seed yield of winter wheat (Triticum aestivum L.) under rain - fed Mediterranean condition. Bulgarian J. Agric. Sci. 16 (6), 733 - 739.

Drija, V. and Kazakove, V. (1975) Effectiveness of different organic manures condition with superphosphate on chernozem soil in the Ukraine. (C.F. Field Crop Abst. 1977 (7), 382.)

Eghball, B., Ginting, D. and Gilley, E. (2004) Residual effects of manure and compost applications on crop production and soil properities. Agron. J. 96, $442-447$.

El Naggar, S.M., Haggag M.E.A., Nofal, Z.A. and Ramadan, M.R. (1991) Effect of intercropping berseem on barley, and wheat. A. Growth and yield. Egypt. J. Appl. Sci. 6 (4), $92-112$.

Eskandari, H. and Ghanbari, A. (2010) Effect of different planting pattern of wheat (Triticum aestivum) and bean (Vicia faba) on grain yield, dry matter production and weed biomass. Not. Sci. Biol. 2 (4), 111 - 115.

Fininsa, C. (1997) Effect of planting, relative planting date and inter-row spacing on a haricot bean/maize in monoculture and legume based rotation. Can. J. Soil Sci. 81, 21 - 31.

Gregorich, E.G., Drury, C.F. and Baldock, J.A. (2001) Changes in soil carbon under long term maize in monoculture and legume - based rotation. Can. J. Soil Sci. 81, 21 - 31.

Kapur, M.I. (1995) Direct and residual value of sulphatation can filter cake as a nitrogen source for crops. J. of the Indiansoe. of Soil Sci. 43, 63 - 66.

Mahmoud, M.R. (2000) Improvement of soil fertility and sorghum production as a result of compost and phosphorus fertilizers application. Minia J. of Agric. Research and Development, 20 (3), 553 - 572.

MSTAT-C (1980) A Micro Computer Program of the Design Management and Analysis of Agronomic Research Experiment. Michigan State Univ., USA.

Ramamurthy, V. and Shivashankav, K. (1995) Residual effect of organic matter and phosphorus on growth and yield of sunflower. Farming - System, 11 (3-4), 16 - 20.

Shafshak, S.F. and El-Debaby, A.A. (1975) "Crop Rotation and Agriculture Intensification”. Agron. Dept., Moshtohor, Agric. College, Zagazig Univ. Press.

Snedecor, G.W. and Cochran, W.G. (1980) "Statistical Methods". $7^{\text {th }}$ ed., Iowa State Univ. Press, Ames, Iowa, USA.

Thorsted, M.D., Olsen, J.E. and Weiner, J. (2006) Width of clover strips and wheat rows influence grain yield in winter wheat/white clover intercropping. Field Crops Res. 95, 280 - 296.

Egypt. J. Agron . 36, No.2 (2014) 
Yilmaz, F., Atak, M. and Erayman, M. (2007) Identification of advantages of maizelegume intercropping over soliary cropping through competition indices in the East Mediterranean region. Turk. J. Agric. 32, $111-119$.

(Received 3 / 8 /2014; accepted 28/10/2014)

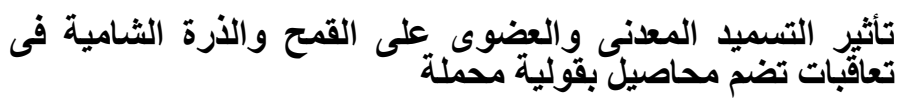

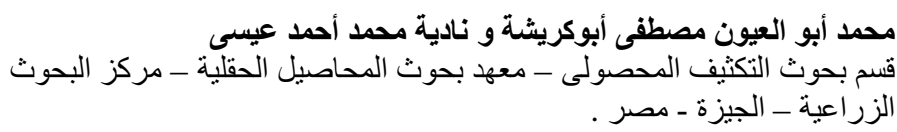

نفذت التجربة بمحطة بحوث ملوى (مصر الوسطى) خلال ثلاث سنوات متتالية

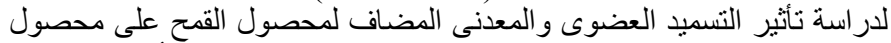

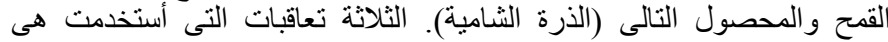

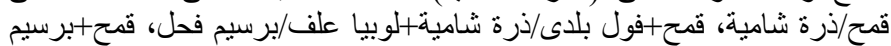

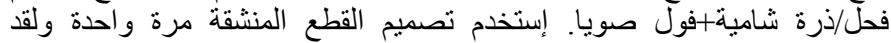

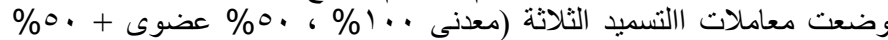

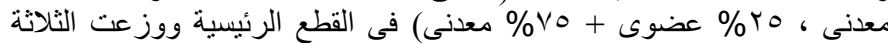
تعاقبات على القطع الثقية فى ثلاث مكررات.

النتائج توضح أن محصول القمح والذرة الثامية كان عاليا عند إستخدام

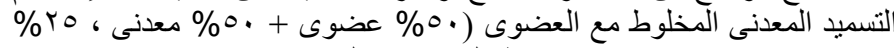

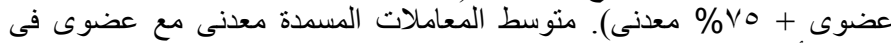

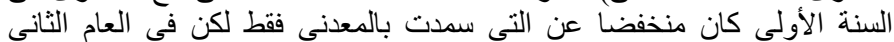
و الثالث كانت المعدلات عالية مع التسميد العضوى مع المعدنى عن التى تم تسميدها معدنى فقط.

التعاقب المحصولى الثالث (قمح + برسيم فحل/ ذرة شامية + فول صويا)

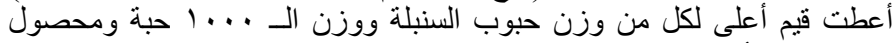

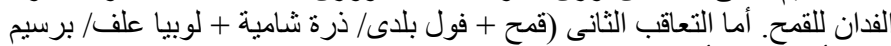
فحل) أعطت قيم أعلى لكل من وزن الـ لـ .. حبة ومحصول الفدان للإرة الثامية.

متوسط الصفات لمحصولى القمح والذرة الثامية عندما تم التسميد بمخلوط السماد العضوى والمعدنى (B.

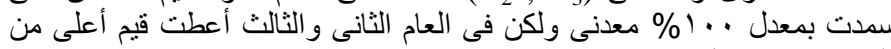

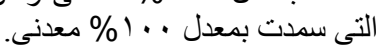

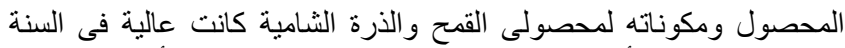
الثالثة عن السنة الثانية وأيضا كان عاليا في السنة الثانية عن السنة الأولى.

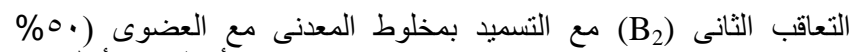

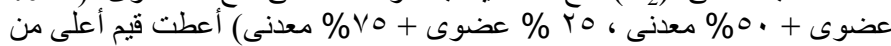
محتوى التربة N, P, K و المادة العضوية عن المعاملات الأخرى.

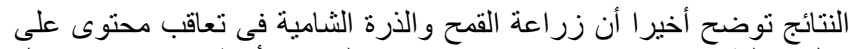

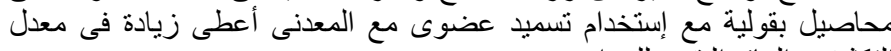
التكثيف و العائد النقى للمز ارع. 